\title{
The Role of Social Work and Social Work Leadership in Pandemic Crisis Intervention
}

\author{
Hai Luo \\ Faculty of Social Work, University of Manitoba, Winnipeg, Canada \\ Email: Hai.Luo@umanitoba.ca
}

How to cite this paper: Luo, H. (2021). The Role of Social Work and Social Work Leadership in Pandemic Crisis Intervention. Open Journal of Social Sciences, 9, 639-650.

https://doi.org/10.4236/jss.2021.95036

Received: April 22, 2021

Accepted: May 28, 2021

Published: May 31, 2021

\begin{abstract}
This summative theoretical paper describes the role of social work in disaster management and pandemic response, as well as the leadership that social workers can provide in pandemic crisis intervention. Past practice and research have identified three major characteristics of social work contributions in disaster management: integrated psychosocial intervention, emphasis on community participation, and application of strengths-focused and asset-driven approaches. Social work leadership, especially transformative leadership in disaster management, is also discussed. This paper aims to provide inspiration from previous successful experience to social workers in the midst of the COVID-19 pandemic intervention, so that practitioners will develop, expand, or strengthen their own disaster management models and establish strong leadership that will lead to success in the intervention process.
\end{abstract}

\section{Keywords}

Social Work, Transformative Leadership, Pandemic, Crisis Intervention, Crisis Management

\section{Introduction}

Disasters have happened frequently in human history. There are two common forms of disasters-natural and technological or human-made (Mathbor, 2007; Rogge, 2004). While crises such as hurricanes, tornadoes, floods, and earthquakes are caused by environmental changes, technological disasters usually are related to or are results of human acts of war, terrorism, mass killing, airliner accidents, and public transit explosions (Rogge, 2004). Social work has a long history in responding to community emergencies and dealing with disaster recovery (Ku, Ip, \& Xiong, 2009), and social work endeavors include delivery of resources and services to affected populations (Galambos, 2005), psychological 
first aid (Pockett, 2006), design and implementation of different programs (Dodds \& Nuehring, 1996), and agency organization (Pyles, 2007).

A pandemic is a unique form of disaster, categorized as a public health emergency (Rosoff, 2008). Social workers' intervention in a public health emergency was first documented during the great worldwide influenza pandemic that caused millions of deaths in 1918 (Kerson, 1979). Historical records indicate that on average three influenza pandemics take place every century, roughly every 30 years (Rosoff, 2008). Since the 1980s, human society has been battling with the global AIDS pandemic. In the $21^{\text {st }}$ century, we have experienced several pandemics, among them SARS in 2003, H5N1 (the bird flu) in 2006, and HINI (the swine flu) in 2009. While there is abundant literature on social work's involvement in disaster management, reports on practice and research about its role in public health emergency response are relatively few (e.g., Blake, 2015; Rosoff, 2008). In the era of rapid technology development, which results in fundamental change of human communication and interaction, the role of social work in disaster management can be redefined and revisited.

This theoretical paper will describe the role of social work during pandemics, as well as the leadership that social workers can perform in pandemic crisis interventions, particularly in interdisciplinary teams. The paper aims to provide inspiration from previous successful experience to those social workers who are in the midst of the COVID-19 pandemic intervention, so that practitioners will develop, expand, or strengthen their own disaster management models and establish strong leadership that leads to success in the intervention process.

\section{Theoretical Underpinnings: Social Work's Role in Disaster Management}

A natural or man-made hazard does not necessarily become a disaster if it does not impact on vulnerable populations (Ariyabandu, 2003; United Nations Development Programme, 2007). A disaster is defined as a "combination of hazards, conditions of vulnerability and insufficient capacity or measures to reduce the potential negative consequences of risk" (Hossain, 2013: p. 160). Disasters induce the losses of lives, materials, economics, and habitable environment. A community's or a society's normal functioning is disrupted or fully stopped, and cannot be restored by the ability of the affected community members and their own resources (Hossain, 2013; Rowlands, 2004, 2013).

Disaster management consists of five basic stages: prevention, preparedness, emergency response, recovery, and mitigation (Hossain, 2013; Rogge, 2004; Rowlands, 2013). While prevention and preparedness are interventions in the pre-disaster phase, emergency response, recovery, and mitigation usually take place in the aftermath. In the case of COVID-19, social workers provided emergency response during the initial impact of the pandemic in local communities, while their services are carried on into the stages of disaster recovery and mitigation. Past practice and research have identified three major characteristics of so- 
cial work practice in disaster management: integrated psychosocial intervention, emphasis on community participation, and application of strengths-focused and asset-driven approaches. These characteristics are elaborated in detail below. This is followed by a discussion on social work leadership, especially transformative leadership, in disaster management.

\subsection{Integrated Psychosocial Intervention}

Many victims of disasters experience traumatic loss resulting from losses of family and friends as well as life-sustaining materials and possessions (Raphael, 1983; Rowlands, 2004). Post-traumatic stress disorder (PTSD) reactions include hyperarousal (e.g., nightmares), intrusion (e.g., reliving), and constriction (e.g., numbing) (American Psychiatric Association, 2013). It is an ethical act for social workers to respond to the psychological breakdowns of community members who are affected by disasters. Common intervention approaches are counselling or therapy, group therapy such as narrative therapy, cognitive behavior therapy (CBT) (Pockett, 2006; Rowlands, 2004), and Critical Incident Stress Debriefing (CISD) (Mitchell, 1983; Mitchell \& Everly Jr., 2001; Raphael \& Wilson, 2000).

In recent years, however, researchers and practitioners have started to question about the effectiveness of psychological intervention and have provided empirical evidence to evoke critical thought. Generally disaster survivors do not experience severe PTSD, even after having faced death and losing loved ones and properties (Silove, 2005). Rowlands (Rowlands, 2013) summarized Raphael \& Stevens's findings as follows:

[O]nly $4 \%$ of a population is anticipated to suffer a severe mental health disorder, such as psychosis, in the 12 months post-disaster (as opposed to $2 \%$ in the general population pre-disaster). Up to half the population could experience moderate to severe psychological distress that does not meet the criteria for disorder and that generally reduces over time through natural recovery without intervention (pp. 22-23).

Upon examining different studies' findings on psychological debriefing with disaster survivors, McNally (2004) found no consistent evidence that it could prevent posttraumatic psychopathology. Furthermore, the data from over 40 years of disaster experiences in Australia repeatedly found that disaster survivors do not access "labelled" mental health services in disaster-affected areas; rather, they prefer to express their thoughts and feelings, as well as acquire support, from fellow community members in other locations, such as recovery centers, laundromats, and community settings (Rowlands, 2013). The best therapy is to meet victims' social tangible needs (safety, living materials, employment and income, and informal social support from and with fellow community members or grassroots organizations, which might be facilitated by professional disaster relief workers (Silove, 2005).

From the social work perspective, an integrated psychosocial response to dis- 
aster should cover psychological first aid, debriefing with affected individuals and groups, needs assessment, and case management of relief work (Hossain, 2013; Pyles, 2007; Rowlands, 2013). Case management (aka "casework") involves assessing individuals' needs, offering psychological first aid, providing tangible supports (e.g., food, clothing, shelter, and safety) to affected people, as well as mobilizing resources to meet the needs of individuals and groups. It consists of outreach, assessment, planning, referring, monitoring, providing information, and advocacy for disaster victims (Pyles, 2007; Rowlands, 2013; Tan, 2004). Social work intervention in disaster encompasses both tangible and mental health aspects (Ku, Ip, \& Xiong, 2009; Pockett, 2006).

\subsection{Facilitating Community Participation}

In many countries, disaster management has been viewed as the government's responsibility and relief work is usually carried out by experts outside the affected community (Hossain, 2013; Allen, 2006). For example, in a 2011 survey study with 67 Chinese social workers and other personnel, the majority of whom had participated in disaster management in the aftermath of the Wenchuan Earthquake in 2008, the government was considered for primarily responsible for many aspects of disaster management, including organizing and mobilizing the community for recovery and restoration, dealing with media, and distributing supplies to disaster victims/survivors ( $\mathrm{Ng}, 2012)$.

Previous literature, however, indicates that top-down or outside-in approaches have not been effective in disaster management (Rowlands, 2004). Hossain (2013) and Pyles (2007) describe a community-based disaster management (CBDM) model adopted by the Government of Bangladesh, with an emphasis on community participation at all stages of disaster management. Relief services provided by outside experts were inefficient because "experts" often were unfamiliar with survivors' perceptions, needs, and community dynamics, and ignorant to local resources and capacities (Hossain, 2013; Rowlands, 2004).

Countries frequently affected by natural disaster, such as Australia and Bangladesh, established national strategies of "bottom-up" disaster management that actively involves community participation from prevention to recovery stages (Pyles, 2007; Hossain, 2013). Emergency Management Australia (Ife, 2002) suggests successful outcomes of disaster management should sustain community members' livelihood and empowerment, which is indicated by access to services and facilities, sense of community safety, healthy community, participation in community life, a sense of belonging, community cohesion, community identity, and economic recovery.

Practitioners and researchers (Hossain, 2013; Mathbor, 2007; Pyles, 2007) recommend inclusive approaches social workers can adopt to enhance community participation: 1) collaboration with grassroots organizations and the most vulnerable members to identify needs and resources, plan, train volunteers, and evaluate programs; 2) recruitment of volunteers from the affected community to 
implement emergency response and recovery plans; 3) enhancing awareness among community members about their roles and duties in disaster management; 4) creating awareness among government officials about recognizing "the social dignity of people and treat them with respect in the policy making process" (Hossain, 2013: p. 167); and 5) empowering the community through strengthening social capital (bonding, bridging, and linking) and mobilizing resources.

\subsection{Focus on Strengths and Assets}

Asset-based community development (the ABCD) model incorporating the social work strengths value, has been applied often in recent disaster management (Ku, Ip, \& Xiong, 2009; Pyles, 2007; Rowlands, 2013). Rowlands (2013) argues that community recovery should not focus solely on needs, but "build upon those resources that the community already controls, and harness those not yet available" (p. 75). Community assets are individuals' capacities, skills, and talents, individual businesses, locally-based public services, civic groups, and non-profit organizations inclusively.

A strengths approach stresses that individuals and community are the experts of their own needs and challenges. Needs-driven disaster management may disempower the local community by promoting the idea that only outside professionals can fix the problem and undermins informal mutual support in the existing networks (Ku, Ip, \& Xiong, 2009; Pyles, 2007). It can also induce a cycle of dependence largely related to governmental actions (Ife, 2002). Through constant relationship-building and rebuilding within and between communities, community members can "contribute their gifts and friendships, adopt collective efforts to rebuild their own community, and use stories and rituals to both celebrate achievements and acknowledge that tragedy is acceptable, inevitable, and a process demanding recovery" (Rowlands, 2013: p. 76).

\section{The Role of Social Work in a Pandemic}

Until the SARS epidemic widely spread in China, Taiwan, Singapore and Canada in 2003 did social workers start to pay attention again to their roles in public health disasters. Using crisis theory, Tan (2004) examined social work intervention in the SARS outbreak in Singapore, including dealing with feelings, assessing danger and threats within a short time, mobilizing resources, and establishing communication channels. Rosoff (2008) in the US and Pockett (2006) in Australia both called for relocating social work action in health emergency response, as well as strategical, systematic plans in case of pandemics. In Canada, a social work certification body, the Ontario College of Social Workers and Social Service Workers (2015), published Pandemic Planning. What are my obligations to provide a general guide for social workers.

The Public Health Agency of Canada (2008) summarizes the particular considerations for social workers, in addition to traditional/normal emergency so- 
cial services, due to the unique characteristics of a pandemic:

- One-stop reception centers are needed more than ever in order to reduce physical connections of community members;

- The use of telephone and other communication modalities for delivery of services become essential;

- Social workers can organize emergency shelters, in conjunction with other governmental and non-governmental agencies, using traditional sites, such as schools and hotels, as well as non-traditional sites;

- Social workers may provide or organize home delivery of groceries, meals, and medications;

- Though no special clothing is required in a pandemic, there is a possible need to deliver essential supplies and self-protection requirements to the community members in isolation or unable to go out;

- Social workers need to consider different modes to deliver common disaster response services: caring for vulnerable groups such as children and older adults, counselling for mental health issues, providing psychological first-aid, bereavement, and alternative financial support, etc.

Reflecting on the abovementioned characteristics of social work intervention in disaster management, namely integrated psychosocial intervention, an emphasis on community participation and a focus on strengths and assets, and social work's role in a pandemic, I will examine the development and common models of social work leadership.

\section{Social Work Leadership}

Compared to other disciplines such as psychology, business, and governmental organizations, social work has a much shorter history of leadership development. Indeed, social work practitioners and leaders have learned and borrowed ideas and experiences from the aforementioned disciplines, including models in organizational psychology or organizational sociology by Max Weber, application of communication in organizations and communitarianism by Amitai Etzioni, and understanding of leadership in business from Fortune 500 company articles.

The literature differentiates management from leadership. In social work practice, however, both are critical. Leadership focuses on goal setting, inspiration, and vision, while management addresses implementation of work plans and coordination of everyday tasks (Mary, 2005; Sullivan, 2016). An applied and pragmatic discipline, social work management serves to solve problems and keep the organization functioning (Brilliant, 2001). Social work leaders are creative, innovative, and inspiring; more importantly, they are more inclusive and altruistic than leaders in business and governmental agencies (Sullivan, 2016; Brilliant, 2001). They ground their leadership in social work values of empowerment and strengths. The Canadian Association of Social Workers (CASW) (2021) quote a social worker Janet $P$., "( $t$ )he power to empower suggests that through our dedi- 
cation and commitments to social justice and equity in social work practice we can create space for diverse voices and perspectives to be heard and explored in ways that create opportunities to understand ourselves and others, worldviews and perspectives in ways that promote socially just communities and policies that help transform society". Strengths perspective is another foundational principle by which social work leadership is conducted. Instead of focusing on individuals' and/or organizations' problems and deficits, strengths-based leadership stresses team members' and organizations' abilities, assets, and resources (Rath \& Conchie, 2008). Popular in social work, as well as in business, military, and education, strengths-based leadership is "a method of maximizing the efficiency, productivity, and success of an organization by focusing on and continuously developing the strengths of organizational resources" (Burkus, 2010).

Three leadership types in social work have been documented and studied: laissez-faire leadership, transactional leadership, and transformational leadership (Bass, 1990; Mary, 2005). Laissez-faire leadership is commonly considered a "hands-off" style due to the absence of actual leadership. The second type, transactional leadership, utilizes both reward and punishment in the process of managing and leading a team, and the leader is a "hands-on" figure who is constantly watching team members' performance and waiting for mistakes to happen. The relationship between the leader and team members is described as an exchange that is based on financial productivity, psychological gain (praise), or political promises. In transformational leadership, the leader motivates team members to pursue their professional and personal growths aligned with the vision of the team/organization. He/she will not micromanage, but trust each member's motivation and creativity in goal setting and implementation toward the greater good (Bass, 1998; Mary, 2005).

Transformational leadership aims to maximize both the teams' and members' potential by encouraging members to integrate their own personal goals and interests with the collective good (Fisher, 2009; Mary, 2005). A transformational social work leader focuses on passion, optimism, political acumen, the ability to look into the future, with a penchant for adventure (Mary, 2005). Leadership theorists have identified five essential components in transformational leadership, the four is (Bass, 1985) and the leader's charisma (Bass \& Avolio, 1990). The five components of transformational leadership are as follows (Fisher, 2009; Mary, 2005; Rowold, 2005):

- Charisma. The leader has high moral standards and is a role model to followers.

- Idealized influence. The leader has a vision for the organization and the ability to draw people together around it.

- Inspirational motivation. The leader motivates team members to have high expectations and motivate them toward action.

- Intellectual stimulation. The leader challenge and enable team members to be creative and innovative in problem solving. 
- Individual consideration. The leader nurtures a supportive environment for self-actualization of team members with goal setting, opportunity, and leadership style best fit for individual members.

As the empirical evidence has shown, not only do social workers adopt transformational leadership naturally due to the common theoretical foundation of empowerment, strengths, participatory action, self-determination, and self-realization (Fisher, 2009; Packard, 2003), but this type of leadership also contributes significantly to successful intervention in social work practice, as indicated by effectiveness, extra effort, and high satisfaction with the leader (Gellis, 2001; Mary, 2005).

Transformational social work leaders concentrate on team members' contextual performance as opposed to task-oriented performance evaluation under traditional leadership approaches (Mary, 2005). Contextual performance consists of five categories of indicators: 1) performing with enthusiasm and extra effort to complete one's own task activities; 2) volunteering to carry out task activities that are originally assigned to other team members; 3 ) helping and cooperating with other team members; 4) following organizational rules and procedures; and 5) supporting and defending organizational visions (Borman \& Motowidlo, 1997; Tafvelin, Hyvönen, \& Westerberg, 2014).

\section{Discussion and Conclusion}

The COVID-19 pandemic began with cases of infection first reported in Wuhan in the Hubei province of China in January of 2020, and has since spread to the rest of the world, including Canada. Besides causing upwards of 3.47 million deaths and infecting over 167 million people (World Meters, 2021) in a year and a half, the pandemic has stalled international economies, halted local, national, and global events, and affected the life and work of literally everyone. Unfortunately, many groups that already experience marginalization are especially vulnerable to virus infection, as well as its harmful social effects. For example, older adults with health conditions and weaker immune systems are affected more easily by the virus; the lockdown and social distancing worsened many older adults' isolation; women and children who experience violence in their homes live daily with abusers due to social isolation measures; there has been an increase in racist and xenophobic acts against people of Chinese origin; and Indigenous people in remote areas are further isolated due to the lockdown. Though these marginalized groups are traditionally social work targeted populations, the challenge to respond in an emergency and the emergent needs created by the crisis are new, due to the health risks caused by the pandemic, as well as the need to maintain social and physical isolation. The role of social work and social work leadership in disaster management, particularly in a pandemic, needs to be redefined and revisited.

In the face of the new challenge posed by the COVID-19 pandemic, practitioners need to move from reactive to proactive actions to achieve preparedness 
for public emergency and disasters. Existing general guidelines on social work in a pandemic, such as Pandemic Planning. What are my obligations published by the Ontario College of Social Workers and Social Service Workers (2015), and The Role of Emergency Social Services in Planning for Pandemic Influenza in Canada by the Public Health Agency of Canada (2008), are limited to providing advice on the work and responsibilities the social work profession most take in a pandemic, without elaborating on social work skills, ethical consideration, use of technology, and training and education for professional preparedness of pandemics.

What is also missing is research and theoretical reflection of social work leadership in the pandemic. Due to the expansiveness of the public health crisis globally, many, if not all, fields of healthcare, public services, governmental organizations, and non-governmental organizations have been involved in the endeavors of stopping the spread of the virus, treating those who are infected, and developing various strategies to increase population safety. The battle with the virus is no longer, and has never been from the beginning, one discipline's duty, but many.

Many social work groups' experience of providing intervention and support in the pandemic has just started to demonstrate the important role of social work and the strengths of social work leadership in interdisciplinary collaboration (International Federation of Social Workers, 2020; Truell \& Crompton, 2020; $\mathrm{Yu}, \mathrm{Tan}, \& \mathrm{Niu}, 2021)$. Respecting various disciplinary expertise and strengths, social workers must move beyond what each profession can do and focus on what all professions can do collaboratively. Social work leaders have the vision of holistic wellbeing of individuals and society as a whole. Social workers are pragmatic, which enables them to mobilize all resources in different professions and create opportunities to generate the best services and facilitate efficient delivery. Social workers should respond to Berg-Weger and Morley's (2020) call: "While we will continue to provide the same services, we may find that, along with our interprofessional colleagues, we can all envision expanded perspectives on our roles (p. 2)".

\section{Conflicts of Interest}

The author declares no conflicts of interest regarding the publication of this paper.

\section{References}

Allen, K. M. (2006). Community-Based Disaster Preparedness and Climate Adaptation: Local Capacity-Building in the Philippines. Disasters, 30, 81-101. https://doi.org/10.1111/j.1467-9523.2006.00308.x

American Psychiatric Association (2013). Diagnostic and Statistical Manual of Mental Disorders (5 ${ }^{\text {th }}$ ed.). Washington, DC: Author. https://doi.org/10.1176/appi.books.9780890425596

Ariyabandu, M. M. (2003). Bringing Together Disaster and Development-Concepts and 
Practice, Some Experiences from South Asia. In P. Sahni, \& M. M. Ariyabandu (Eds.), Disaster Risk Reduction in South Asia. New Delhi: Prentice-Hall of India.

Bass, B. M. (1985). Leadership: Good, Better, Best. Organizational Dynamics, 13, 26-40. https://doi.org/10.1016/0090-2616(85)90028-2

Bass, B. M. (1990). From Transactional to Transformational Learning: Learning to Share the Vision. Organizational Dynamics, 18, 19-31. https://doi.org/10.1016/0090-2616(90)90061-S

Bass, B. M. (1998). Transformational Leadership: Industrial, Military, and Educational Impact. Mahwah, NJ: Lawrence Erlbaum.

Bass, B. M., \& Avolio, B. J. (1990). Multifactor Leadership Questionnaire. Palo Alto, CA: Consulting Psychologist Press.

Berg-Weger, M., \& Morley, J. E. (2020). Editorial: Loneliness and Social Isolation in Older Adults during the COVID-19 Pandemic: Implications for Gerontological Social Work. The Journal of Nutrition, Health \& Aging, 24, 456-458. https://doi.org/10.1007/s12603-020-1366-8

Blake, P. (2015). Pandemic Planning: What Are My Obligations? Considerations for Members of the Ontario College of Social Workers and Social Service Workers. https://www.ocswssw.org/wp-content/uploads/2015/01/Pandemic-Plan-Obligations-Ar ticle.pdf

Borman, W. C., \& Motowidlo, S. J. (1997). Task Performance and Contextual Performance: The Meaning for Personnel Selection Research. Human Performance, 10, 99-109. https://doi.org/10.1207/s15327043hup1002_3

Brilliant, E. (2001). Social Work Leadership: A Missing Ingredient. Social Work, 31, 325-331. https://doi.org/10.1093/sw/31.5.325

Burkus, D. (2010). Strengths-Based Leadership Theory. https://davidburkus.com/2010/04/strengths-based-leadership-theory/\#: :text=Strength s\%2DBased\%20Leadership\%20Theory\%20(also,systems\%2C\%20tools\%2C\%20and\%20 people

Canadian Association of Social Workers (2021). Power to Empower. https://www.casw-acts.ca/en/power-to-empower

Dodds, S., \& Nuehring, E. (1996). A Primer for Social Work Research on Disaster. Journal of Social Service Research, 1, 27-56. https://doi.org/10.1300/J079v22n01_03

Fisher, E. (2009). Motivation and Leadership in Social Work Management: A Review of Theories and Related Studies. Administration in Social Work, 33, 347-367. https://doi.org/10.1080/03643100902769160

Galambos, C. M. (2005). Natural Disasters: Health and Mental Health Considerations. Health and Social Work, 30, 83-86. https://doi.org/10.1093/hsw/30.2.83

Gellis, Z. (2001). Social Work Perceptions of Transformational and Transactional Leadership in Health Care. Social Work Research, 25, 17-25.

https://doi.org/10.1093/swr/25.1.17

Hossain, A. (2013). Community Participation in Disaster Management: Role of Social Work to Enhance Participation. Antrocom Online Journal of Anthropology, 9, 159-171.

Ife, J. (2002). Community Development: Community-Based Alternatives in an Age of Globalisation ( $2^{\text {nd }}$ ed.). Frenchs Forest, Australia: Pearson.

International Federation of Social Workers (2020). The Role of Social Workers across Asean Countries in Response to COVID-19 Pandemic.

https://www.ifsw.org/the-role-of-social-workers-across-asean-countries-in-response-to -covid-19-pandemicl 
Kerson, T. S. (1979). Sixty Years Ago: Hospital Social Work in 1918. Social Work in Health Care, 4, 331-343. https://doi.org/10.1300/J010v04n03_08

Ku, H. B., Ip, D., \& Xiong, Y. (2009). Social Work in Disaster Intervention: Accounts from the Grounds of Sichuan. China Journal of Social Work, 2, 145-149. https://doi.org/10.1080/17525090903211408

Mary, N. (2005). Transformational Leadership in Human Service Organization. Administration in Social Work, 29, 105-118. https://doi.org/10.1300/J147v29n02_07

Mathbor, G. M. (2007). Enhancement of Community Preparedness for Natural Disasters: The Role of Social Work in Building Social Capital for Sustainable Disaster Relief and Management. International Social Work, 50, 357-369.

https://doi.org/10.1177/0020872807076049

McNally, R. J. (2004). Psychological Debriefing Does Not Prevent Posttraumatic Stress Disorder. Psychiatric Times, 21.

https://www.psychiatrictimes.com/ptsd/psychological-debriefing-does-not-prevent-pos ttraumatic-stress-disorder

Mitchell, J. T. (1983). When Disaster Strikes the Critical Incident Stress Debriefing Process. Journal of Emergency Medical Services, 8, 36-39.

Mitchell, J. T., \& Everly Jr., G. S. (2001). Critical Incident Stress Debriefing: An Operations Manual for CISD, Defusing and Other Group Crisis Intervention Services (3rd ed.). Ellicott City, Md.: Chevron Publishing Corporation.

Ng, G. T. (2012). Disaster Work in China: Tasks and Competences for Social Workers. Social Work Education, 31, 538-556. https://doi.org/10.1080/02615479.2011.581277

Ontario College of Social Workers and Social Service Workers (2015). Pandemic Planning: What Are My Obligations.

https://www.ocswssw.org/wp-content/uploads/2015/01/Pandemic-Plan-Obligations-Ar ticle.pdf

Packard, T. (2003). The Supervisor as Transformational Leader. In M. J. Austin, \& K. M. Hopkins (Eds.), Supervision as Collaboration in the Human Services: Building a Learning Culture. Thousand Oaks, CA: Sage.

Pockett, R. (2006). Learning from Each Other: The Social Work Role as an Integrated Part of the Hospital Disaster Response. Social Work in Health Care, 43, 131-149. https://doi.org/10.1300/J010v43n02_09

Public Health Agency of Canada (2008). The Role of Emergency Social Services in Planning for Pandemic Influenza in Canada. https://www.homelesshub.ca/sites/default/files/s5ipjxpu.pdf

Pyles, L. (2007). Community Organizing for Post-Disaster Social Development: Locating Social Work. International Social Work, 50, 321-333. https://doi.org/10.1177/0020872807076044

Raphael, B. (1983). The Anatomy of Bereavement. New York: Basic Books.

Raphael, B., \& Wilson, J. P. (2000). Psychological Debriefing: Theory, Practice and Evidence. Cambridge: Cambridge University Press. https://doi.org/10.1017/CBO9780511570148

Rath, T. \& Conchie, B. (2008). Strengths-Based Leadership: Great Leaders, Teams, and Why People Follow. Gallup Press.

https://search-ebscohost-com.uml.idm.oclc.org/login.aspx?direct=true\&db=nlebk\&AN $=580021 \&$ site $=$ ehost-live

Rogge, M. E. (2004). The Future Is Now: Social Work, Disaster Management, and Traumatic Stress in the $21^{\text {st }}$ Century. Journal of Social Service Research, 30, 1-6. 
https://doi.org/10.1300/J079v30n02_01

Rosoff, P. M. (2008). The Ethics of Care: Social Workers in an Influenza Pandemic. Social Work in Health Care, 47, 49-59. https://doi.org/10.1080/00981380801970814

Rowlands, A. (2004). Reappraising Social Work's Contribution to Recovery from Disaster and Trauma: Applying a Strengths Perspective. Asia Pacific Journal of Social Work and Development, 14, 67-85. https://doi.org/10.1080/21650993.2004.9755955

Rowlands, A. (2013). Disaster Recovery Management in Australia and the Contribution of Social Work. Journal of Social Work in Disability \& Rehabilitation, 12, 19-38. https://doi.org/10.1080/1536710X.2013.784173

Rowold, J. (2005). Multifactor Leadership Questionnaire Psychometric properties of the German Translation. Mind Garden, Inc. https://www.mindgarden.com/documents/MLQGermanPsychometric.pdf

Silove, D. (2005). The Best Immediate Therapy for Acute Stress Is Social. Bulletin of World Health Organization, 83, 75-76.

Sullivan, W. P. (2016). Leadership in Social Work: Where Are We? Journal of Social Work Education, 52, S51-S61. https://doi.org/10.1080/10437797.2016.1174644

Tafvelin, S., Hyvönen, U., \& Westerberg, K. (2014). Transformational Leadership in the Social Work Context: The Importance of Leader Continuity and Co-Worker Support. The British Journal of Social Work, 44, 886-904. https://doi.org/10.1093/bjsw/bcs174

Tan, N. T. (2004). Crisis Theory and SARS: Singapore's Management of the Epidemic. Asia Pacific Journal of Social Work and Development, 14, 7-17. https://doi.org/10.1080/21650993.2004.9755939

Truell, R., \& Crompton, S. (2020). To the Top of the Cliff: How Social Work Changed with COVID-19. Rheinfelden: International Federation of Social Workers.

United Nations Development Programme (2007). Human Development Report 2007/2008. Links between Natural Disasters, Humanitarian Assistance and Disaster Risk Reduction: A Critical Perspective. UNDP Human Development Report Office. https://doi.org/10.1057/9780230598508

World Meters (2021). https://www.worldometers.info/coronavirus/

Yu, Z. H., Tan, W. J., \& Niu, L. Y. (2021). The Experiences of the Good Companions Response Team during the COVID-19 Pandemic in Wuhan, China: A Multiprofessional Team Led by Social Workers. Asia Pacific Journal of Social Work and Development, 31, 132-138. https://doi.org/10.1080/02185385.2020.1854843 